Bulletin d'études orientales

\title{
Legal Pluralism among the Court Records of Medieval Egypt
}

Phillip I. Ackerman-Lieberman

\section{(2) OpenEdition}

\section{Journals}

Electronic version

URL: http://journals.openedition.org/beo/2904

DOI: $10.4000 /$ beo.2904

ISSN: 2077-4079

Publisher

Presses de l'Institut français du Proche-Orient

\section{Printed version}

Date of publication: 1 April 2015

Number of pages: $79-112$

ISBN: 978-2-35159-707-1

ISSN: 0253-1623

\section{Electronic reference}

Phillip I. Ackerman-Lieberman, «Legal Pluralism among the Court Records of Medieval Egypt», Bulletin d'études orientales [Online], LXIII | 2015, Online since 01 April 2017, connection on 06 May 2019. URL : http://journals.openedition.org/beo/2904 ; DOI : 10.4000/beo.2904 


\title{
Legal Pluralism among the Court Records of Medieval Egypt
}

\author{
Phillip I. ACKERMAN-LIEBERMAN
}

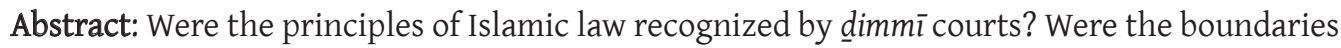
between Muslim and $\underline{\operatorname{dimm}} \bar{\imath}$ courts permeable, or did dimmī leaders try to solidify their power over their communities by controlling $\underline{\operatorname{dimm}} \bar{\imath}$ access to Muslim courts? To what extent did the pressures of litigants' forum-shopping affect the decisions of dimmi courts? The JudeoArabic documents of the Cairo Geniza are an invaluable source for the study of legal history in medieval Egypt. The Geniza contains a plethora of court records - which occasionally allude to "Arabic documents" admitted into the Jewish court. What role did these documents play in the decisions of the Jewish court? In this paper, I survey the court records of the Geniza in order to explore legal pluralism in the Fătimid and Ayyūbid periods, revealing the court

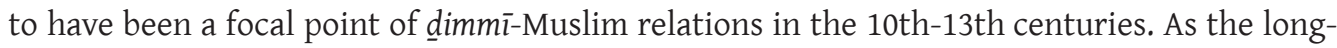
understood legal pluralism of the Fāțimid period gave way to Ayyūbid support of Šăfi i jurists in the late 12th century, I will show Jewish courts which long recognized documents composed in Muslim courts and which even composed their own documents in a manner that might have allowed them to be read into evidence in Muslim courts to have attempted to limit dimmi use of Muslim courts and to arrogate to themselves alone the power to adjudicate matters of interest to the Jewish community. I bring evidence of forum-shopping and legal pluralism between Muslim and dimmi courts, and I trace the waxing and waning of this pluralism against the historical trajectory of the medieval period in Egypt, giving particular attention to the court of Abraham Maimonides, which (I will argue) responded to an environment of decreasing legal pluralism by arrogating to itself sole power to deal with certain legal issues. This response is particularly manifest in a resurgence of documents written in Hebrew instead of Judeo-Arabic.
\end{abstract}

Keywords: Egypt, Ayyūbids, courts, scribes, judicial pluralism, Abraham Maimonides, dimmī-s, jews, Cairo Geniza.

Résumé : Les principes du droit islamique étaient-ils reconnus par les dimmī-s ? Les frontières

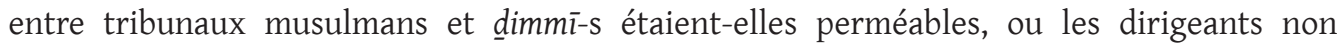
musulmans s'efforçaient-ils de renforcer leur autorité sur leurs communautés en contrôlant l'accès de leurs ouailles aux tribunaux musulmans? Dans quelle mesure la pression exercée par le forum-shopping des plaideurs affectait-elle les jugements des dimmī-s? Les documents 
judéo-arabes de la Geniza du Caire constituent une source inestimable pour l'étude de l'histoire judiciaire de l'Égypte médiévale. Nombre d'archives judiciaires y font allusion aux "documents arabes" acceptés par le tribunal juif. Quel rôle ces documents jouaient-ils dans les décisions prises par ce dernier? Dans cet article, j'explore les archives de la Geniza afin de mieux comprendre le fonctionnement du pluralisme judiciaire aux périodes fatimide et ayyoubide - révélant combien les tribunaux se trouvaient au centre névralgique des relations entre dimmī-s et musulmans entre le $\mathrm{X}^{\mathrm{e}}$ et le XIII ${ }^{\mathrm{e}}$ siècle. Tandis qu'à la fin du XII ${ }^{\mathrm{e}}$ siècle, le pluralisme bien connu de la période fatimide s'effaçait devant le soutien des Ayyoubides aux juristes šāfiites, les tribunaux juifs qui avaient longtemps accepté les documents composés dans les tribunaux musulmans - et qui avaient même élaboré leurs propres actes de manière à leur permettre d'être lus et reconnus comme preuves par les musulmans - tentèrent de limiter le recours des dimmì-s aux tribunaux musulmans, et de s'arroger le pouvoir de juger seuls les affaires de la communauté juive. J'explore les usages du forum-shopping et du pluralisme judiciaire entre tribunaux musulmans et dimmī-s, et j'analyse les fluctuations de ce pluralisme au regard de l'évolution historique de l'Égypte médiévale. Je m'attarde en particulier sur le tribunal d'Abraham Maimonide, qui réagit à un contexte de réduction du pluralisme judiciaire en s'arrogeant le pouvoir de traiter certaines affaires, ce qui se manifeste notamment par la résurgence de documents où l'hébreu remplace le judéo-arabe.

Mots-clés :Égypte, Ayyoubides, tribunaux, scribes, pluralisme judiciaire, Abraham Maimonides, dimmī-s, juifs, Geniza.

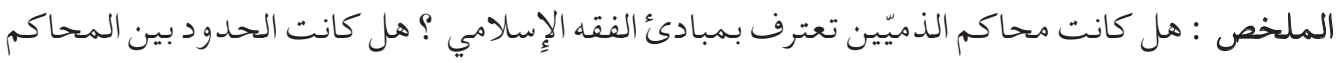

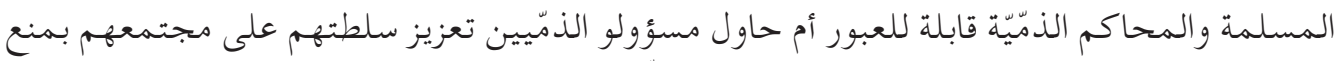

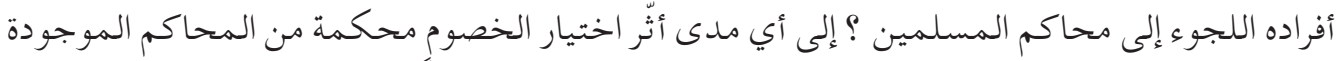

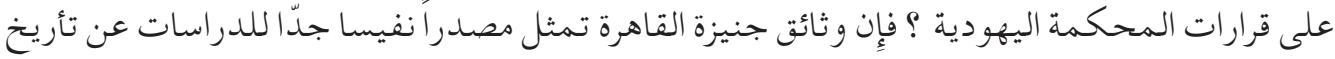

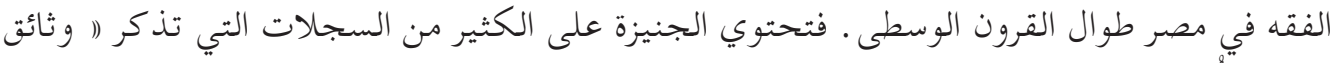

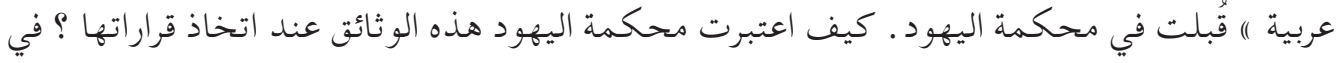

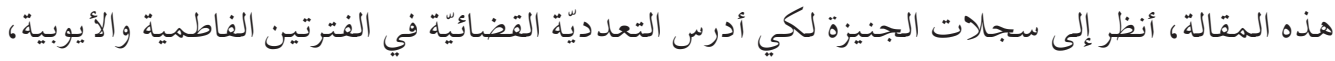

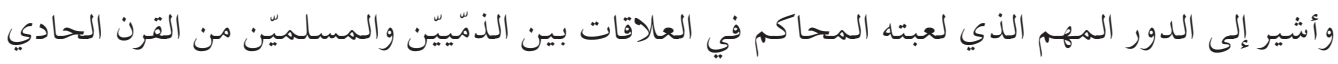

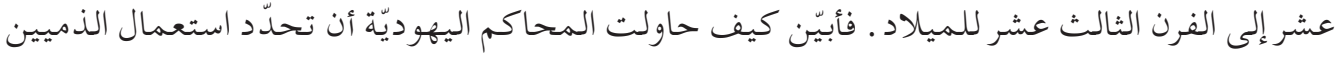

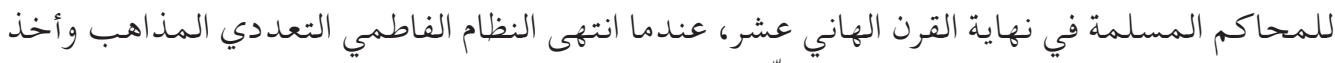

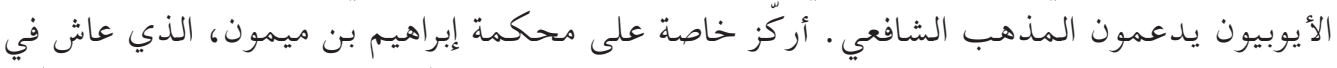

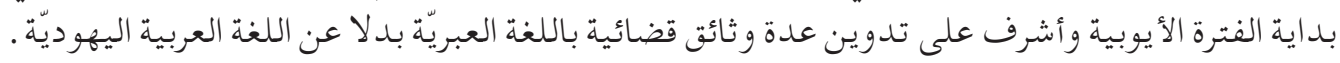

$$
\begin{aligned}
& \text { الكلمات المحوريّة : الأيوبيون، مصر، محكمة، كتّاب، التعدديّة القضائيّة، إبراهيم بن ميمون، أهل }
\end{aligned}
$$

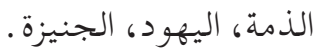




\section{Introduction}

From late Antiquity, Jewish legal sources accepted as legitimate documents produced by non-Jewish courts; the Mishna explains in Tractate Gittin (1:5) that "all documents from the non-Jewish court are accepted except for divorce decrees and emancipation decrees, despite the fact that they are signed by non-Jews". Although the Talmud restricts this permission further, rejecting documents bestowing a gift (Talmud Bavli Gițtin 10b), and this further restriction is often followed in the geonic responsa of the first few centuries of Islam $^{1}$ the Jewish courts of medieval Egypt perpetuated the rabbinic permission accepting certain documents written in non-Jewish - in their case, Islamic - courts. The documents of the Cairo Geniza regularly attest not only to purchase and sale documents having been written in Arabic - and hence seemingly having been produced by an Islamic court, since records of the Jewish court itself are found in Hebrew, Aramaic, and Judeo-Arabic - but the Geniza even attests to partnership agreements written in Arabic and emerging from Islamic courts being read into evidence and accepted by the Jewish court of Fătimid Egypt.

Likewise, the Jewish court seems to have produced documents which might have been used in Islamic courts. The language of some of the legal documents of the Cairo Geniza diverges from the formularies of the post-Talmudic geonim and addresses concerns resident in Islamic law that are absent from Jewish law. ${ }^{2}$ The inclusion of such language suggests that Jewish court scribes were aware of the possibility that their documents might find their way into an Islamic court, and that they wished to produce documents whose effect would withstand challenges in such courts. Jeanette Wakin has already pointed out the prominence of this phenomenon (called ihtiyāt in Arabic) among Muslim scribes wishing to produce documents whose validity would be maintained in courts whose judges ascribed to Islamic legal schools other than that of the scribes themselves. ${ }^{3}$ Yet until now, this phenomenon has not been seen as transcending communal lines and used by dimmīs writing documents to be used in Islamic courts.

As Fātimid rule gave way to Ayyūbid rule in the late 12th century, and the Fātimids' legal pluralism in choosing $q \bar{a} d \bar{l} \overline{-}$-s from a range of Islamic legal schools gave way to Ayyūbid and Mamlūk preference for adherents of the Šăfi ī School, ${ }^{4}$ a small but significant number of documents emerges from the Jewish court written in Hebrew. ${ }^{5}$ The obvious consequence of this language choice was that such documents could no longer be introduced into an Islamic court. Rejecting the explanation that this choice was the result of an influx of non-Arabicspeaking Jews into Egypt in the early 13th century, I will argue over the course of this paper that the shift into Hebrew reflected the Jewish court's attempt to arrogate to itself legal power and control in the face of a waning legal pluralism on the part of Muslim rulers.

1. See, for example, MÜllER 1966, \#199, SHERIRA BEN ḤANINA, HAI BEN SHERIRA et al. 1965, \#82.

2. For a detailed discussion of this, including an example, see my article ACKERMAN-LIEBERMAN 2010.

3. For Wakin's analysis, see ȚAHĀWI and WAKIN 1972, particularly p. 1-10.

4. See Ira Lapidus' discussion of this phenomenon in LAPIDUS 1972.

5. See, for example: Mosseri A11, TS 12.126, TS AS 147.3, TS 18 J 1.31, and ULC Add 2586. 
Setting the Stage: Notarial Practice and Forum-Shopping in Medieval Egypt

\section{"Islamic" Documents in Jewish Courts and "Jewish" Documents in Islamic Courts}

In her seminal study of the formulary al-šurūt al-kabir of the 10th century jurist Ahmad b. Muhammad al-Ṭahāwī (d. 321/933), Jeanette Wakin points out a central problem in the implementation of Islamic law in its medieval context. ${ }^{6} \mathrm{~A}$ diversity of views among legal scholars could produce unintended consequences if a contract was litigated before an authority other than the one who initially composed it. ${ }^{7}$ Differences of law from one court to another could challenge or even vitiate the intent of a contract. Uncertainty as to how a contract will be understood by a later court charged with adjudicating that contract exists in the maintenance of every legal relationship. However, where various authorities in a given locale might not only have held different legal viewpoints concerning one or another clause of a particular contract but might even have subscribed to different legal schools which implied not only a distinct (even if largely-overlapping) body of positive law but also a different analytic method of legal exegesis, the danger that the contractual parties' initial intentions might not be preserved - or perhaps worse, the danger that one or another party might manipulate differences in law to its advantage - was heightened.

Wakin points out that medieval jurists were well-aware of this problem, and they developed the tools to cope with it: model contracts appearing in the medieval Islamic formulary literature

had to be valid in all schools simply because business itself cut across the borders of all schools. Thus it was up to the notary to satisfy every view, or at least to avoid offending any one of them. In other words, he had to draw up a contract that would be absolutely safe in court. ${ }^{8}$

Employing a principle known as ihtiyāt, or "precaution", notaries could append to their contacts clauses that met the requirements of one legal school and were unnecessary but otherwise unobjectionable to another. The case of a sale effected through an agent provides us with a clear example, as Wakin writes: "Where the jurists disagree over whether the acting buyer or the principal pays the price to the seller, Țahāwī names them both: 'the agent paid the price out of the capital of the one who commissioned him'." ${ }^{9}$ To a jurist who held that the agent was responsible for paying the seller, the inclusion of the additional clause would have been unnecessary but also unobjectionable, but without this clause another jurist who held the principal responsible for making this payment would have nullified the sales agreement. Ihtiyat t was an important tool in the hands of the notary for

6. See her study, ȚAHĀWII and WAKIN 1972, particularly p. 1-10.

7. See ȚAHĀĀI and WAKIN 1972, p. 32.

8. ȚAḤ̄ĀI and WAKIN 1972, p. 1-10.

9. ȚAHĀWII and WAKIN 1972, 34. 
overcoming ihtiläf, difference of opinion, whether that difference emerged from scholastic method - that is, from ușūl al-figh - or from disagreement in positive law - that is, fur $\bar{u}^{c}$ al-figh.

Jewish notaries functioning in the medieval Islamic world might have faced an even broader range of ihtila $f$, where their constituents from the dhimmi communities would also have had access to competing Muslim courts. In this situation, Jewish notaries might have wished to employ precaution in a manner that allowed their documents to hold up not only in the face of a range of opinion among Jewish jurists but might also have accounted for the possibility that the jurists evaluating their documents might not be Jewish at all. of course, incorporating language into Jewish documents that might retain their validity in Islamic courts suggests that - even if only under certain circumstances - Islamic courts would accept documents written in the Jewish courts. Otherwise, Jewish notaries would have had little reason to reach beyond Jewish law in their legal formulae. Likewise, both Jewish legal literature and documentary evidence of actual court records from the Cairo Geniza, the treasure trove discovered in the back of the Rabbanite synagogue of Fusțāt and the bulk of whose documentary materials draw from the 11th-13th centuries, ${ }^{10}$ consider the possibility that Jewish courts might accept documents written and notarized in nonJewish courts. If the audience for documents produced under Ṭahāwī’s Šurūt al-kabīr and identified by Wakin included jurists of different madhabs, one might say that that Jewish scribes understood Jewish law to function as yet another madhab in the multivalent legal landscape of medieval Egypt; and Islamic courts' acceptance of documents produced in the Jewish court would suggest a similar understanding on the part of Islamic courts.

In this article, I plan to review briefly both the Jewish legal literature on documents written in non-Jewish courts and the actual court records of the Cairo Geniza that reflect both the recognition by the Jewish court of documents written in Muslim courts and the understanding that documents written in the Jewish court would find their way into Muslim courts. As I have already intimated, Jewish notaries' knowledge that their constituents could and would forum-shop led to the development of a "Jewish ihtiyatt" that can be detected in the language of their documents. I will bring to light some of the details of this ihtiyatt.

However, the historical record suggests that the judicial pluralism, if you will, indicated by the reliance in Muslim courts upon documents written in the Jewish court and vice versa, was not universal. While Jewish scribes of the 11th and 12th centuries who produced the court records of the Geniza wrote documents that, it would seem, could be used in an Islamic court, ${ }^{11}$ a small but substantial segment of the Geniza record shifts subtly in the early 13th century. After describing the ihtiyăt employed by Jewish scribes in the classical period of the Geniza, I will trace the demise of this ihtiyatt and set it in relief against the

10. For an introduction to the documents of the Cairo Geniza, see GoITEIN 1967, I, p. 1-28.

11. For a discussion of this phenomenon and a specific example, see my article, ACKERMAN-LIEBERMAN 2010. 
political and legal conditions of the period to reveal Jewish court practice as an important tool for negotiating Muslim-dimmi relations in the medieval period as a whole.

First, a few of the classical Jewish sources on the use of documents written in non-Jewish courts: I have already mentioned that the Mishna permits most documents written in nonJewish courts, although the Talmud constrains this permission slightly. Writing in the late 12th century, Moses Maimonides (1138-1204 C.E.) narrows the field further, explaining in the Mishneh Torah that the only documents that may be notarized in the non-Jewish court are documents of sale and debt documents. ${ }^{12}$ Yet in their response, the geonim - that is, the sages of the rabbinic academies of Iraq and the Land of Israel who follow on the close of the Talmud in the 6th century and who retain a measure of spiritual hegemony over the broad expanse of medieval Jewry up to the beginning of the 11th century - maintain the Talmud's restriction on documents of gift in a number of their responsa, but generally accept documents written in non-Jewish courts. ${ }^{13}$

However, it would seem that this practice was at times understood to be controversial; another (anonymous) geonic responsum explains that fear of counterfeiting has led some Jewish courts not to accept documents written in the non-Jewish (here, certainly Muslim) courts. Yet the gaon writes that in his own locale, Baghdad, "non-Jewish courts only accept circumspect, noble, and wealthy witnesses... exceptional in their faith, called al-mu 'addilin, "trustworthy". ${ }^{14}$ The gaon therefore not only opens the door to Muslim documents being accepted in the Jewish courts of Baghdad, but also in the large cities in Iraq where witnesses might be held to a similar standard. On the other hand, he writes that "there are some villages and other distant places where the matter is otherwise... and we do not accept their documents". A second concern, beyond the reliability of witnesses, lies in the possibility that documents might be forged wholesale, as opposed to their witnesses simply giving false testimony; here, the gaon explains that both Jewish and Muslim court practice protects against forgery by demanding that confirmatory witnesses document the testimony of testifying witnesses. According to the gaon, the shared Jewish-Muslim practice of confirmatory testimony is sufficient to insure the authenticity of documents properly composed in Muslim courts.

Occupying a liminal role between legal theory and practice, Jewish legal formularies account for non-Jewish law. The formulary collection of the Babylonian leader Hai Gaon (d. 1038 C.E.) includes in the language for a release document indemnity from further action "of any court, whether a Jewish court or a non-Jewish court", ${ }^{15}$ and the formulae both for a release document and a loan document declares the document's validity "as any valid document of any court, Jewish or otherwise". ${ }^{16}$ The latter language is also seen

12. Maimonides, Mishneh Torah, Laws of Lenders and Borrowers 27:1.

13. See, for instance, MÜLLER 1966, \#199, SHERIRA BEN HANINA, HAI BEN SHERIRAet al. 1965, \#82.

14. SHERIRA BEN HANINA, HAI BEN SHERIRAet al. 1965, \#278.

15. HAI BEN SHERIRA and ASSAF 1930, p. 23 1. 13.

16. HAI BEN SHERIRA and ASSAF 1930, p. 24 1. 10. 
in the formulary of the 9th/10th century Egyptian-born Iraqi authority Sa'adya Gaon in his formula for a release document. ${ }^{17}$ Interestingly, the later rabbinic authority Judah ben Barzillai of Barcelona (late 11th/early 12th century) includes no such mention of nonJewish courts. It may have been the case, then, that the geonic authorities writing under Muslim rule had a particular concern for Jewish documents travelling into Muslim courts and vice versa, while those under Christian rule did not.

The actual documentary evidence of the Cairo Geniza bears out this concern. Even a cursory search of Geniza documents reveals tens of fragmentary court records that allude to so-called "Arabic documents" (Judeo-Arabic, al-kutub al-'arabiya) with various grammatical forms. These Arabic documents often define an economic relationship or transaction that is subsequently addressed in the Jewish court. Thus, for example, a document from the Bodleian Library (shelf-mark Bodl Ms Heb a 3.1) from the year 1139-1140 C.E. alludes to an Arabic document which established a particular sugar factory as having been partly an inheritance and partly a sale from an individual named Berakhot to his two sons. ${ }^{18}$ The Jewish document, written in Judeo-Arabic, records that the two sons entered into a partnership in that factory with two outside investors, and the Jewish document relies on the Arabic document to establish the physical boundaries of the sugar factory itself. The Jewish document explains that the two sons are to put up their ownership in the factory as collateral corresponding to the investment of their fellows who were silent partners, and that the partners should record the details of their pledge on the back of the Arabic document. It is clear that the Arabic document not only served as a record registering the bounds of the ownership of real property, but that it also continued to serve as an integral part of the transaction between Jews as they recorded their pledge on its verso.

Likewise, a document from the Taylor-Schechter Geniza Collection in the Cambridge University Library (shelf-mark TS 16.138) written in Alexandria in 1077 C.E., releases two partners from all obligations pursuant to their partnership. ${ }^{19}$ The text of the release agreement is typical of the genre, but what is perhaps less typical is the description of the partnership from which these Jewish merchants seek release - as if channeling the Mishna's validation of documents from non-Jewish courts, one of the merchants explains that "I, Khalaf b. 'Ezron, have an Arabic document bearing the testimony of non-Jews, concerning a partnership which was between us, and we have been separated from it, and nothing from the Arabic document remains binding". ${ }^{20}$

We may conclude, then, that rabbinic legal materials and Geniza documents alike point to the general acceptance of documents produced in the Muslim courts, but what about the converse? What can Jewish materials tell us about the possibility that documents produced

17. BEN-SASSON 1983-1985, p. 2021.16.

18. For a brief discussion of this document, see GOITEIN 1967, I, p. 367.

19. For a transcription and translation of this document, see my dissertation, ACKERMAN-LIEBERMAN 2007, II, p. 131-135.

20. 1l. 18-19, translation mine (ACKERMAN-LIEBERMAN 2007, II, p. 134). 
in the Jewish courts might find their way into Muslim courts as valid evidence? For this, we may look in Jewish documents for legal elements that are absent from Jewish formularies or classical Jewish legal compendia. When Jewish scribes included such materials in Arabic, they were doing more than simply translating Jewish formularies into Judeo-Arabic, since that task was already done for them by Sa'adya Gaon when he composed his own JudeoArabic formulary. Their inclusion of such Arabic phrases, then, should be seen as deliberate and worthy of examination. ${ }^{21}$

The inclusion of legal phraseology in Jewish documents that would have had no relevance before Jewish legal authorities, yet would have played an important role for their Muslim counterparts, hints at the very sort of "precaution" outlined by Jeanette Wakin. We find just such language in the Geniza documents. For example, as I have written elsewhere concerning a pair of documents from the Geniza concerning the sale and delivery of a slave-girl dated to 1226 C.E., the Jewish documents contain with one possible exception all of twelve items described in Islamic formularies as essential to the bill of sale for a slave. ${ }^{22}$ Thus, clauses such as the guarantee against a flaw in the object of sale, a guarantee known in Arabic as daman al-darak, are absent from Jewish formularies yet are part and parcel of their Islamic counterparts. This phenomenon might be explained as the result of Jewish court scribes simply being conservative, including in documents as many stock phrases as they could to protect the document's validity. However, this explanation is challenged by the fact that scribes actually varied their language based on the specific needs of their customers: the language of each of the two documents concerning the sale of this single slave girl is actually unique. Each document was written to respond to the specific legal concerns and needs of the party who purchased it - it is worthwhile remembering at this point that scribes are paid for their work, perhaps even by the line! Aware that legal challenges could bring their clients to either the Jewish or the Muslim court, it would seem that Jewish scribes exercised their craft accordingly.

While Jewish courts recognized that their litigants might seek justice in Islamic courts, and scribes might even have facilitated this, geonic authorities also seem to have understood such forum-shopping to challenge their own influence with the Jewish community. ${ }^{23}$ An unnamed geonic writer records a decree that "all who come before me and before the Jewish court after the Gentile court must pay a fine of one dinar". ${ }^{24}$ Even more pointed is the decree understood by scholars to have been made by the court of Moses Maimonides in

21. Ben-Sasson published fragments of Sa'adya's Judeo-Arabic formulary in BEN-SASSON, 1983-1985.

22. See my article ACKERMAN-LIEBERMAN 2010.

23. For a discussion of such forum-shopping, see BRODY 1998, p. 62-63, which explains the geonic concern that Jewish women "might seek the assistance of Islamic authorities"; see also SIMONSOHN 2011, for a more in-depth discussion of similar concerns on the part of the geonim. In a similar vein, Tamer El-Leithy describes monks in the Mamlūk period eliciting legal opinions from multiple mufti-s in parallel: "Based on the results they received from the different muftis, the monks could select the school most advantageous to them, and then bring a lawsuit before a judge of that school" (EL-LEITHY 2011, p. 407).

24. Cited in MANN 1919, p. 139-140. 
1187 C.E. against anyone who goes to the Muslim courts at all. ${ }^{25}$ Maimonides declares in a responsum that "[i]t is a sin and a transgression for a Jewish person to go to a Gentile court, unless he is unable to go to a Jewish court". ${ }^{26}$ In the 7th century in Iraq, forum-shopping was an unavoidable concomitant of living in the Islamic environment. One well-known example of this phenomenon concerns the so-called "rebellious wife": while the Talmud mandates a year-long waiting period before granting a divorce to a woman who refuses to fulfill her marital or conjugal obligations, in the middle of the 7th century the geonic leaders of the academies of Sura and Pumbedita

promulgated a decree which called for the divorce to be granted without delay (in return for which the wife's property rights were slightly curtailed). This ordinance was apparently motivated by the fear that Jewish women, frustrated by the cooling-off period imposed by talmudic law, might seek the assistance of Islamic authorities and possibly even convert to Islam in order to dissolve their marriages without delay. ${ }^{27}$

Jewish authorities relied on other strategies as well to deal with forum-shopping: somewhere along the way, a fine was implemented by the geonim for using Muslim courts and Jewish courts in competition with one another. Yet by the late 12th century, the response of the Jewish court in Egypt was more assertive in its struggle against Jewish use of Muslim courts, with Maimonides declaring this to be forbidden unless no other option was available.

Of course, the decree of Maimonides' court was not implemented in a vacuum. The legal environment in Egypt underwent significant changes in the late 12th century as Fātimid tolerance for $q \bar{a} d \bar{l}$-s of different Sunnī stripes gave way to Ayyūbid preference for those of the Šâfi'i school. ${ }^{28}$ While individual personalities, proclivities, and a judge's particular scholastic approach might have dictated a range of rulings in the Fātimid period, concentrating around a single Islamic legal school would have meant a convergence in the Islamic courts, at least, around a single corpus of positive law. The Jewish courts might have been seen as falling somewhere on the continuum of the other, Muslim, madhab-s, under the Šìī Fātimids; not so with the rise of their Sunnī successors. Ayyūbid officials also demanded the power to ratify even Jewish judicial appointments. ${ }^{29}$ The Jewish court seems to have responded to the waning of judicial pluralism and internal control by defensively closing the doors of Muslim courts to Jewish litigants: hence the decree of Maimonides' court a decade and a half after the inauguration of Ayyūbid rule. Henceforth (at least nominally) Muslim courts would be forbidden to the Jews - as long as there were Jewish courts available.

\footnotetext{
25. See Maimonides' responsa, ed. Freimann, \#155 and \#295-6; ed. Blau, \#27 and \#408.

26. Responsa Maimonides, ed. Freimann, \#295.

27. BRODY 1998, p. 62-63.

28. For a discussion of this waning legal pluralism and the intensifying preference of the Ayyūbids for Shāfi $1 \overline{1}$ jurists, see LAPIDUS 1972.

29. Cf. GOITEIN 1967, II, p. 405-406.
} 
The Waning of Legal Pluralism and the Jewish Response - the Case of Abraham Maimonides

The torch lit by Moses Maimonides protecting the fiefdom of the Jewish courts was picked up by his son Abraham (d. 1237 C.E.), who succeeded his father as head of the Jewish community of Egypt in 1204 C.E. If we review the documentary production of Abraham's court, we see the resurgence of the use of Hebrew in legal documents in a court whose members would actually have been quite familiar with Judeo-Arabic as a working language for Jewish legal documents. That is to say, a small but significant percentage of the documents from Abraham's court that appear in the Geniza are written in Hebrew rather than Judeo-Arabic. If Maimonides père applied moral suasion and perhaps even the ban to keep Jewish litigants out of Muslim courts, the Hebrew documents of his son's court made it impossible for those litigants to step into Muslim courts: while Judeo-Arabic documents could have been literally read into evidence in Muslim courts, where the verbiage of the documents would largely overlap with the Arabic of the Muslim court itself, the Hebrew of Abraham Maimonides' court would have been essentially unintelligible in its specifics to Arabic speakers. As I will argue in the balance of this article, by shifting to Hebrew, Abraham Maimonides' court shut down the behavior mentioned in the geonic responsum of using Jewish courts and Muslim courts in competition, perhaps revisiting in the Jewish court a conclusion reached in a Muslim court. Henceforth, documents initiated in the Jewish court would have to stay in the Jewish court.

This sort of proactive, even aggressive, behavior in imposing changes to meet communal needs may be seen as very much in character for Maimonides fils. While he has often been dubbed an "innovator", ${ }^{30}$ Elisha Russ-Fishbane has recently demonstrated that these "innovations" were actually the rulings of his father Moses Maimonides, feeding "Abraham's self perception as the bearer of the Maimonidean patrimony". ${ }^{11}$ There are certainly important differences between the character of father and son: while Maimonides père was somewhat conservative in his imposition of rulings that would cause intra-communal tension,

The same spirit of caution failed to motivate Maimonides' son, who considered it his duty to reform deviations from the original rite. His personal account of his liturgical reforms attests to his decision to assert his spiritual and temporal authority upon the community, even when his proposals led to internal discord. ${ }^{32}$

Indeed, one of Abraham's supporters in the controversy surrounding his liturgical "innovations" explained that Abraham and his followers "stated that this was an ancient part of their revealed law, and that they have revived an aspect of religious practice that had

\footnotetext{
30. See, for instance, Rustow's discussion of Abraham's "liturgical innovations" (RUSTOW 2009, p. 140ff.).

31. RUSS-FISHBANE 2012, p. 192. Indeed, Russ-Fishbane is explicit that "[i]n spite of these differences, Abraham presented his reform as a direct continuation of his father's original ruling" (ibid., p. 204).

32. RUSS-FISHBANE 2012, p. 203.
} 
fallen into desuetude". ${ }^{33}$ It is important to see Abraham for what he was: not an innovator but a visionary willing to make uncomfortable decisions that he thought were necessary to facilitate the greater good, even if they generated controversy in the short term. The shift in language choice within a swath of documents emerging from Abraham's court speaks to this willingness. Indeed, we may see Abraham's reversion to Hebrew as consistent with the idea that he was returning to an earlier practice with his liturgical "innovations".

The connections between Abraham's liturgical and notarial activity are sharpened further as we review the challenges Abraham faced. When opponents of the liturgical reform complained to a local notable (styled "the faqih") that Abraham had imposed changes on longstanding communal practices, the latter "filed a brief in his own defense in which he claimed that he had adopted the liturgical innovations in the privacy of his own home but had never attempted to impose them on his congregation" ${ }^{34}$ In the same vein, Abraham explained in a responsum that prostration during prayer "is permissible and he himself engaged in it, but he would never insist that his questioners adopt it, 'for you are at liberty to do as you like"'. ${ }^{35}$ Marina Rustow argues that Abraham's charisma and power may well have led his opponents (and even his followers) to mistake Abraham's proposed changes for imposed ones. ${ }^{36}$ Nonetheless, Abraham's willingness to implement changes that might not be employed universally could explain why he would have allowed some of the documents of his court to continue to be written in Judeo-Arabic even if he might have wished for all scribes to switch to Hebrew. Indeed, Abraham may have not had the political capital to effect this change en masse, a change that would have been especially difficult to implement given that scribes had been writing court documents almost exclusively in Judeo-Arabic for more than a century. The use of Hebrew would have required a reversion to earlier formulary models and (as we shall see) was easiest to implement for documents distinctive to the Jewish community and for which competing Judeo-Arabic models would not have existed. ${ }^{37}$

The Adoption of Judeo-Arabic by the Jews of Islamic Lands

In his article, "On the Interplay of Arabic and Hebrew in the Cairo Geniza Letters", 38 Mark Cohen alludes to a protracted timeline of the establishment of Judeo-Arabic as the "dominant literary language of the Jews of Arab lands". According to this timeline, Jewish communities in the lands of Islam were exposed to "Middle Arabic" from the middle

33. RUSTOW 2009, p. 142, citing TS AS 182.291. I cite here Rustow's own translation and not that of Geoffrey Khan's translation in Arabic and Legal Administrative Documents in the Cambridge Genizah Collections (Cambridge: Cambridge University Press, 2006), Doc. 66, 1. 4ff.

34. RUSTOW 2009, p. 142. The document describing this vignette is TS Arabic Box 51.111.

35. RUSTOW, 2009, p. 143.

36. RUSTOW, 2009, p. 143.

37. One example of this sort of document is the prozbul described below.

38. COHEN 2007. 
of the 7th century ${ }^{39}$; and with the urbanization of the Babylonian Jewish community in the early 'Abbāsid period, ${ }^{40}$ Judeo-Arabic began to occupy a prominent place in oral communication, though Aramaic continued to be spoken in small towns and rural areas in Babylonia. ${ }^{41}$ However, it was only with the first half of the 10th century that Jews began to adopt Judeo-Arabic as a literary language, ${ }^{42}$ and still later before it assumed dominance. Cohen describes this protracted timeline as including an intermediate or transitional stage, the earlier part of which can be described by the primacy of Hebrew seen in the famous letter and responsum by Amram Gaon (r. 861-872 C.E.) outlining the proper order of the prayer service, including both liturgical materials and narrative instructions in Hebrew; and the latter part including the important "letter" of Sherira Gaon (r. 968-1006 C.E.) recounting the birth and flowering of rabbinic literature, written in Aramaic. The object of Cohen's analysis is the letters of the Cairo Geniza. Accepting the received wisdom that the grammatical conventions of Geniza letters followed conventions similar to those in spoken "Middle Arabic", ${ }^{43}$ Cohen understands the linguistic choice in letters to have followed that in speech, writing that these letters "begin to mount at the beginning of the 11th century, after Aramaic had given way to Arabic as the spoken tongue of most of the Jews of the Islamic world and when Arabic was becoming solidly established as their literary medium". ${ }^{44}$ Thus, in Cohen's view, the dominance of Judeo-Arabic in letters from the 11th century, edging out both Hebrew and Aramaic, should be seen as an adjunct to the rise of Judeo-Arabic as the language of daily life in the Jewish community. Although the geonim of both Palestine and Babylonia wrote in both Hebrew and Judeo-Arabic through the 12th century, Cohen explains that these community leaders "employ[ed] Hebrew much the same way that speakers of European vernaculars from the elite (notably churchmen) used Latin, especially when corresponding about political and ecclesiastical affairs". ${ }^{45}$ Cohen notes that such letters imitated the high register of classical Arabic, employing rhymed prose (sağ). Cohen is thereby able to show Jewish-Arabic literary contacts by comparing attributes of Hebrew and Arabic literary production, and revealing language choice to be a decision dictated by the status of its users and by its content.

In contrast, Rina Drory turns to structuralist/functionalist models to explain the transformation and eventual stabilization of language choice among the Jewish community. Seeing the first half of the 10th century as a period of great flux, Drory describes the formation of a new stable pattern in language usage:

\footnotetext{
39. BLAU 1999, p. 19.

40. For a discussion of development of an urban Jewish population in the early Abbasid period, see ASHTOR 1959, p. 147. For a description of the early Abbasid period itself, see KENNEDY 1981.

41. BLAU 1999, p. 19-20.

42. DRORY 2000, p. 158-159.

43. Joshua Blau discusses the phenomenon of "Middle Arabic" and its connections with Judeo-Arabic in BLAU 1999, p. 1-50.

44. COHEN 2007, p. 20.

45. COHEN 2007.
} 
The triple language situation prevailing in writing at this time was thus actually only temporary, as Arabic encroached upon Aramaic and replaced it. It was an intermediate stage between the previous situation, in which Aramaic and Hebrew had divided up the functions of the written language, and the future situation, when Arabic and Hebrew would divide those functions, although not necessarily according to the same divisions as in the previous situation. ${ }^{46}$

According to Drory, the period prior to contact with Arabic revealed the multilingual Jewish community to employ Hebrew and Aramaic in distinctive literary functions: while Aramaic was used for "informative writing", Hebrew was used for liturgical poetry and other roles which "gave great preference to the poetic and festive functions of the language, largely at the expense of comprehensibility". ${ }^{47}$ After the development of Jewish literary contacts with Arabic and primarily through the mediation of the Karaite manifestation of medieval Jewish culture, which had rejected Aramaic as a "Rabbanite" language from the first half of the 9th century, Rabbanite culture beginning with the works of Sa'adya Gaon (r. 928-942 C.E.) turned to Judeo-Arabic for essay-writing since it "satisfied the needs for precise expression which could be understood by all". ${ }^{48}$ Yet in this transitional period certain works served a number of functions, which demanded their composition in both Hebrew and Judeo-Arabic versions. Thus, Drory explains that Sa'adya composed versions of his anti-Karaite treatise Sefer ha-Galuy and his biblical dictionary Egron (which should, like Sefer ha-Galuy, also be understood as a refutation of Karaite exegesis) not only in JudeoArabic but also in Hebrew since this "gave the learned author an opportunity to show off his command of the language". ${ }^{49}$ Over time and particularly in the period following Sa adya, "Arabic writing accommodated the communicative (or, rather, referential) function of the language, [while] Hebrew writing accommodated its festive and grandiloquent function". ${ }^{50}$ Thus, liturgy, secular poetry, and artistic prose either persisted in Hebrew or assumed a Hebrew form; while biblical exegesis, legal writings, philosophy, grammar, poetics, and letters assumed a Judeo-Arabic guise. Perhaps the clearest evidence of the role of this functionalism in Jewish literary production is Sa'adya's own prayer-book, which supplies liturgical texts in Hebrew ${ }^{51}$ and instructions in Judeo-Arabic. ${ }^{52}$ According to Drory, language choice was not dictated by content per se but by the social role or function of that content.

The legal documents of the Geniza follow the trajectory described here for letters and literary sources, with Hebrew fading from the notarial scene in favor of Judeo-Arabic and eventually resurging slightly in the early 13th century. However, while the contour of that

\footnotetext{
46. DRORY 2000, p. 159.

47. DRORY 2000, p. 160.

48. DRORY 2000, p. 167.

49. DRORY 2000, p. 168.

50. DRORY 2000, p. 171.

51. With the obvious exception of those liturgical texts such as the Qaddish whose Aramaic manifestation predates Sa'adya's time.

52. See, for example, Davidson's publication of Sa'adya's prayer-book, SA'ADYA BEN JOSEPH, DAVIDSON et al. 1970.
} 
trajectory is the same, it would seem that Hebrew persisted longer in legal documents than it did in letters and literary sources. Scribes' reliance on existing formula models as an aid to composing documents might have slowed the adoption of Judeo-Arabic by scribes, whether these scribes relied on literary works such as the aforementioned Sefer ha-Shetarot of Hai Gaon (939-1038 C.E.) (itself actually containing formulary exemplars primarily in Aramaic), copies of old court records, or actual disused documents themselves. The introduction of Sa'adya's own Judeo-Arabic formulary would certainly have spurred on the adoption of Judeo-Arabic by court scribes around the late 10th century, but the Geniza does reveal a few legal documents written in Hebrew in the first half of the 11th century. ${ }^{53}$ Legal documents in Aramaic persist, ${ }^{54}$ but Judeo-Arabic definitively conquered Hebrew in legal documents by the middle of the 11th century.

\section{The Maimonidean Riposte}

\section{The Resurgence of Hebrew in the Early 13th Century}

Although the analyses of Cohen and Drory are essentially schematic in that Aramaic did not entirely disappear from the literary corpus of the Jewish community in Islamic lands, persisting in talmudic texts and continuing to appear in legal phraseology and legal document-forms well beyond the period of transition Cohen and Drory describe, the JudeoArabic/Hebrew bilingualism which these scholars describe persisted in a stable pattern for several hundred years. However, as S.D. Goitein notes, this pattern would change subtly at the beginning of the 13th century. Referring to the production of deeds and documents, Goitein writes:

At the beginning of the thirteenth century there was a Hebrew revival, caused partly perhaps by the increasing influx of Jewish scholars from France and Germany into the East and partly by the fact that Maimonides' Code itself was written in easy and lucid Hebrew, which recommended the use of that language for the compiling of legal documents also. ${ }^{55}$

Thus, the court of Abraham Maimonides, who ruled from his father's death in 1204 C.E. until his own death in 1237 C.E., reveals through the documents of the Cairo Geniza a small but significant stratum of documents produced in Hebrew written by a court that equally had at its disposal Hebrew, Aramaic, and Judeo-Arabic, though it operated in a legal environment that had already employed Judeo-Arabic in its deeds, documents and legal opinions almost exclusively for roughly two hundred years, with the exception of

53. Cf., for example, Bodl Ms Heb d 66 f.121 (dated 1027 C.E.); ENA NS 18.26 (dated 1038 C.E.), ENA NS 17.21 (dated 1040 C.E.), Bodl Ms Heb c 28 f.41 (dated 1043 C.E.), and TS 18 J 2.12 (dated 1050 C.E.).

54. Cf., for example, TS 10 J 26.1 (dated 1065 C.E.), TS 13 J 1.16 (dated 1066 C.E.), and TS 12.8/TS 10 J 4.9 (dated 1070 C.E.).

55. GOITEIN 1959, p. 193-194. 
formulaic language at the beginning and end of documents, often written in Hebrew or Aramaic, and Hebrew and Aramaic legal tropes persisting from talmudic sources.

Amidst Goitein's apparent uncertainty as to the precise causes of this resurgence of Hebrew, his explanation of the phenomenon should be understood as multifaceted: first, the influx of European scholars, who presumably would not have understood JudeoArabic, meant that Judeo-Arabic would no longer have fulfilled the communicative function upon which both Cohen and Drory draw in their analyses of linguistic shift; and, second, Maimonides' choice of Hebrew in composing his legal code expanded the role of Hebrew into the legal domain, an expansion taken up by Abraham Maimonides in the dayto-day management of his court. However, it is unclear how this latter explanation fits into the analyses of Cohen and Drory. First, would Cohen's parallel between the Hebrew of the Geonic elite of the 12th century and European "churchmen" apply to Maimonides' legal code, and particularly to the court records and deeds of Abraham Maimonides' court, which were written not for the elite but rather to respond to the needs of litigants in their use of the court to negotiate quotidian life; and, second, how would Drory understand the historical circumstances surrounding Abraham Maimonides' court to affect both the communicative function of language in general and the grandiloquent or festive role of Hebrew in specific to play a part in its introduction both in legal codes and in actual court records at the beginning of the 13th century?

I will now briefly review the historical conditions in which the court of Abraham Maimonides functioned and revisit Goitein's explanations for the resurgence of Hebrew in this court in the early 13th century. In light of the historical analyses which have emerged since Goitein's time, his explanation of this phenomenon will be challenged. From this discussion, I propose that the resurgence of Hebrew in Abraham Maimonides' court was not intended to enhance the communicative role of the court in the first instance, but rather that political changes in the setting of late 12th century and early 13th century Egypt called for a transformation in the role played by Hebrew as used by the Jewish elite adduced by Cohen and in the grandiloquent function of Hebrew adduced by Drory that found form in this resurgence.

\section{Maimonides' Choice of Language: Communicative and Grandiloquent Functions}

In his Introduction to the Code of Maimonides, Isadore Twersky explains that despite the plethora of linguistic options in which to compose his code, including various registers of Hebrew, Talmudic Aramaic, and even Judeo-Arabic, Moses Maimonides' "decision to compose the Mishneh Torah in the language of the Mishnah, so that it should be easily understood by the greatest number of people' was... the natural and unavoidable conclusion" ${ }^{56}$ This conclusion is perhaps surprising given Drory's analysis, which ascribes to Hebrew the festive or grandiloquent role in contradistinction to the communicative

56. TWERSKY 1980, p. 330. 
role which she ascribes to Judeo-Arabic. Indeed, Twersky considers the possibility that Maimonides' statement in a responsum concerning the Book of the Commandments - that "I deeply regret having written this work in Arabic, because all people ought to read it..." ${ }^{57}$-implies that Maimonides wrote the Book of Commandments in Arabic in order to make it possible for "all people" to read it, expressing Maimonides' regretful acceptance of a social reality that Judeo-Arabic and not Hebrew served the communicative function. That the statement in Maimonides' responsum might simply be describing a reality with which he happens to be unhappy is supported by Maimonides' expression elsewhere that Hebrew is a perfect or ideal language, in contrast to the "confused" nature of Arabic: in his letter to his translator Samuel b. Tibbon (d. 1232 C.E.), Maimonides even writes that Arabic is but "Hebrew which has been corrupted a little". ${ }^{58}$ Thus, translating the Book of the Commandments into Hebrew, a venture to which Maimonides aspires in the aforementioned responsum, would clearly demonstrate the master's command of the language, an important step in establishing his authoritative role as head of the Jewish community of Egypt, though not necessarily broadening the audience whom Maimonides might have expected to read the Book of the Commandments. However, Twersky rejects this reading of Maimonides' responsum in favor of what he calls "a more plausible and enlightening interpretation": 59 that the Mishneh Torah was written in Hebrew for the sake of world Jewry as a whole, including non-Arabic-speaking Jewry.

Twersky's explanation concerning Maimonides' choice of language, essentially that "[a] code for the entire nation, rather than for its Arabic-speaking segment, had to be in Hebrew" ${ }^{60}$ is indeed attractive, and certainly represents the received scholarly wisdom. ${ }^{61}$ On the other hand, Israel Ta-Shma's analysis of the Mishneh Torah's acceptance in Italy ${ }^{62}$ suggests that the language of composition of Maimonides' works was not necessarily a factor in their accessibility and adoption by non-Arabic-speaking Jewish communities. Indeed, as explained by Ta-Shma, Maimonides' Commentary on the Mishnah, composed in JudeoArabic, was translated into Hebrew and widely-accepted in Italy well before his Mishneh Torah, despite the fact that the latter needed no translation. ${ }^{63}$ Nonetheless, although TaShma's research challenges the actual role linguistic choice played in communication, it does not necessarily challenge the possibility that Maimonides' own perception was that the communicative function demanded that he compose the Mishneh Torah in Hebrew. With Maimonides' responsum open to varying interpretations, it would seem that the role of communication per se in Maimonides' choice of language is somewhat unclear.

\footnotetext{
57. TWERSKY 1980, citing MAIMONIDES and BLAU 1986, II, p. 725, \#447.

58. Cited in HOPKINS 2005, p. 94.

59. MAIMONIDES and BLAU 1986, \#335.

60. TWERSKY 1980, p. 336.

61. See, for instance, IBN ḦAZM and SHĀKIR 1928.

62. TA-SHMA 2001.

63. TA-SHMA 2001, p. 85, 87.
} 
However, it is also possible that in composing the Mishneh Torah, Maimonides wished instead to make recourse to the grandiloquent function of Hebrew by linking his work to the canonicity of sacred Jewish texts written in Hebrew, supporting the model proposed by Drory. This sentiment is expressed by his statement that "I have entitled this work Mishneh Torah, for the reason that a person who first reads the Written Law and then this compilation, will know from it the whole of the Oral Law, without having occasion to consult any other book between them". ${ }^{64}$ Without the mediation of the Aramaic texts of the Talmud or the Arabic legal monographs of the geonim, Maimonides is clearly drawing on the sacrality of works composed in Hebrew within the Jewish mindset. On the other hand, it would seem that the broad audience which Maimonides clearly intends to address, even he only intends the Jews of Muslim lands, would extend beyond the religious elite imagined by Cohen when he describes Hebrew as the province of the elite used in discussing political or religious affairs. Despite the unclear role of the communicative function in Maimonides' choice, it seems clear that the grandiloquent function identified by Drory played an important role in Maimonides' choice of language in composing the Mishneh Torah, while the role of Hebrew in internal communication within the geonic elite described by Cohen did not.

\section{Hebrew as a Vehicle for Communication in 13th Century Court Records}

Finding the grandiloquent function of Hebrew to have played a key role and the communicative function to have played an unclear role in Maimonides' choice of language in composing the Mishneh Torah makes for a similar analysis of these functions in light of the historical circumstances in which the Jewish community of Egypt found itself around the time of Maimonides' son Abraham Maimonides. Exploring these factors may allow for a reevaluation of Goitein's assessment that it was both the influx of French and German scholars into Egypt and Palestine at the beginning of the 13th century and Maimonides' own choice of Hebrew with which to compose his supreme legal code that influenced the court of Abraham Maimonides and effected the resurgence of Hebrew in documents and deeds revealed by the Geniza. First, even without recourse to Twersky's reading that Maimonides' intended audience extended beyond the Jewish communities in the Islamic sphere, the possibility that the choice of Hebrew in the court records of Abraham Maimonides relied upon the communicative function of the language within the lands of Islam should be considered, particularly in light of early 13th century immigrations from France and Germany to the East described by Goitein. Additions to the sixteenth-century chronicle Shevet Yehudah of the Spanish historian Solomon b. Verga record that "[i]n the year 4971 (1211 C.E.) God inspired the Rabbis of France and England to go to Jerusalem. They numbered more than three hundred..."65 Many of these scholars made their way to Egypt en route to Palestine, though many of them made it no farther than Egypt. This

\footnotetext{
64. TWERSKY 1980, p. 30.

65. CUFFEL 1999, p. 61.
} 
would seem to underpin the narrative described by Goitein. However, Alexandra Cuffel argues not only that these migrations did not begin in the 13th century, but also that the makeup of the immigrant population was more populist than suggested by Ibn Verga and subsequent interpreters of the migration of French Jews to Egypt and Palestine. In light of Geniza documents brought to light by Goitein himself, as well as Elhanan Reiner's analysis of immigration to Palestine in the period, ${ }^{66}$ Cuffel argues that "while the rabbis were probably the leaders of this community of emigrants much as they were in Europe, they were not the only Jews to be part of the French aliyah" ${ }^{67}$ Indeed, Cuffel's reading of the sources, and in particular the Geniza document TS $12.299,{ }^{68}$ suggests that one group of a hundred immigrants was accompanied by only seven rabbis; and Cuffel records Reiner's challenges to the accuracy of Ibn Verga's report, describing it as hagiography. ${ }^{69}$ Nonetheless, the French scholars who did actually make their way to Egypt were treated with particular reverence by the Jewish legal elite of Egypt in the early 13th century; Cuffel points out that Abraham Maimonides bestowed extraordinary praise on some of these authorities: "We saw that they were great sages, possessing wisdom, understanding, piety and sense. We rejoiced in them and they were happy with us and we did them honor as was our obligation". ${ }^{70}$ A number of these scholars went on to positions in the Jewish court, including Anatoli b. Joseph of Lunel (or Marseille), ${ }^{71}$ who became dayyan (judge) in Alexandria during the time of Maimonides, a post in which he remained for a time after the latter's death, though he also served the court in Fustāt during the time of Abraham Maimonides.

The prominence of these French scholars explains Goitein's conjecture that it was the immigration of these scholars and their rise to judicial positions that demanded the resurgence of Hebrew in the court of Abraham Maimonides, perhaps as a resolution to the apparent difficulty that these scholars "were often not fluent in Arabic, and, as judges, had to take recourse to interpreters, a procedure not permitted by Jewish law". ${ }^{72}$ However, there are some problems with this conjecture: the difficulty enumerated by Goitein might explain the use of Hebrew in cases presented to Abraham Maimonides on appeal from these French

\footnotetext{
66. REINER 1988.

67. CUFFEL 1999, p. 72.

68. Transcribed from the Judeo-Arabic, translated into Hebrew and briefly introduced in GOITEIN and HACKER 1980, p. 338-343, excerpted and translated into English in CUFFEL 1999, p. 71.

69. CUFFEL 1999, p. 80 and n. 71.

70. Cited in CUFFEL 1999, p. 76 and n. 56.

71. For details concerning the life of Anatoli b. Joseph, including citations to both scholarly literature and Geniza documents, see GIL 1976, p. 384-385 n. 21.

72. GOITEIN 1967, I, p. 67.
} 
judges $^{73}$ or other correspondence with these judges, but the vast majority of Abraham Maimonides' responsa seem to have been composed in Judeo-Arabic, ${ }^{74}$ significantly including his retort to a responsum of Anatoli b. Joseph himself. ${ }^{75}$ Furthermore, many of the Hebrew documents of Abraham Maimonides' court suggest that the court in Fusțāt was the court of first instance ${ }^{76}$ in which case the deeds and records produced by the court were produced for the litigants themselves rather than for a non-Arabic-speaking judge, whether in Alexandria or Fustāat itself. It is difficult to see how producing documents in Hebrew in such circumstances would have helped the French immigrant elite.

Furthermore, Goitein's own analysis of the Geniza documents challenges his claim that the French émigrés were incapable of communicating in Judeo-Arabic: following the death of Anatoli b. Joseph, a controversy erupted in which the elders of the Alexandrian community chafed at the idea of appointing a Byzantine or French Jew (Rümī or Ifranjī) in his place. ${ }^{77}$ Cuffel explains that "[i]t is tempting to conjecture that Anatoli himself did not know Arabic, and that the community did not want a repeat performance". ${ }^{78}$ However, the community's eventual appointment of one "Samuel" as judge demanded "that the statute invoked did not disqualify foreigners as such, but only those who were not fluent in the language of the country. As a matter of fact, another scholar from France, fluent in Arabic, was appointed as Anatoli's successor". ${ }^{79}$ Cuffel is surely correct that the existence of such a statute "suggests that such appointments had been made in the past and [had] proven unsatisfactory" ${ }^{80}$ but the appointment of Samuel (who is explicitly described as fluent in Arabic) over the initial objections of the Alexandrian leadership also proves her point that "some of the French were able to adapt linguistically" ${ }^{81}$ Both Goitein and Cuffel discuss the difficulties encountered by French émigrés in finding gainful employment due to the linguistic barrier; 82 in the case of the aforementioned Samuel, who succeeded Anatoli

73. For a discussion of Maimonides as appellate judge, see GOITEIN 1959; Abraham Maimonides undoubtedly followed his father in this role. Although Goitein later came to see Maimonides as a mufti (for our purposes, we might describe a mufti as a legal expert providing opinions that would help judges make their decisions at law) rather than as an appellate judge, Goitein would likely have understood Maimonides' use of Hebrew (rather than Judeo-Arabic) to have facilitated Hebrew-speaking judges' understanding of his opinions.

74. For Abraham Maimonides' responsa, see the edited version of Goitein and Freimann (ABRAHAM BEN MOSES BEN MAIMON, FREIMANN et al. 1937).

75. cf. ABRAHAM BEN MOSES BEN MAIMON, FREIMANN et al. 1937, p. 161-173, \#102-104, especially the introduction to \#104, p. 170. Note that Halper does not believe Abraham Maimonides' retort to be directed at Anatoli b. Joseph himself (see ABRAHAM BEN MOSES BEN MAIMON, FREIMANN et al. 1937, p. 167 n. 1), though Goitein and Freimann do not seem to agree (see ABRAHAM BEN MOSES BEN MAIMON, FREIMANN et al. 1937, p. 169 n. 32 ).

76. See, for example: Mosseri A11, the appointment in Fustāt of an executor; TS 12.126 and TS AS 147.3, partnership agreements; and TS $18 \mathrm{~J} 1.31$ and ULC Add 2586, documents related to real estate transactions.

77. For a discussion of this controversy, see GOITEIN 1967 and CUFFEL 1999, p. $74 f f$.

78. CUFFEL 1999, p. 74.

79. GOITEIN 1967, I, p. 67.

80. CUFFEL 1999, p. 74.

81. CUFFEL 1999, p. 75.

82. Cf. GoITEIN 1967, I, p. 67 and CUFFEL 1999, p. $75 f f$. 
b. Joseph, these difficulties provided the impetus for him to learn Judeo-Arabic sufficiently well to assuage the concerns of the communal elders and to serve as community judge. Significantly, Samuel's ascension to the judgeship comes around fourteen years after a student of Samuel writes: "... He does not know how to speak Arabic. How will he succeed ?"83

Although it is clear that the Egyptian community did experience a significant influx of non-Arabic speaking Jews around the time of Abraham Maimonides, it is not entirely clear that the selective use of Hebrew seen in the court of Abraham Maimonides would actually have responded to the needs of French émigré judges to communicate in Hebrew rather than Judeo-Arabic, nor is it clear that those judges remained incapable of communicating in Judeo-Arabic long into their Egyptian sojourn. French sages were certainly accorded a preferential status and accorded great respect by Egyptian communities, but evidence from the Geniza suggests that at least some of these émigrés assimilated linguistically over time.

Finally, it is important to note that linguistic assimilation can take place on a number of levels. The aforementioned Samuel apparently understood Arabic sufficiently well to appease the Alexandrian elders, but there is no reason to assume that he had any particular level of fluency in writing Judeo-Arabic. Cuffel points out that the record of the Alexandrian controversy suggests that European or French Jews in communal posts may have relied on a translator to facilitate court proceedings, ${ }^{84}$ yet this may have indicated an individual who was fully capable of understanding written or oral Judeo-Arabic yet would have encountered some difficulty composing judgments in Judeo-Arabic. ${ }^{85}$ Complicating the definition of linguistic assimilation in this manner problematizes Joshua Prawer's suggestion concerning one of the French émigrés that "Yehiel b. Yișhaq ha-Șarfati, who became a leader in the Jerusalem community, did not know Arabic since his surviving letters are written in Hebrew". ${ }^{86}$ Indeed, Prawer's approach might lead one to conclude that Jehiel b. Eliakim of Aleppo, contemporary and colleague of Abraham Maimonides, ${ }^{87}$ might also not have understood Judeo-Arabic, since his letters are written in Hebrew, ${ }^{88}$ a suggestion bolstered by his own signature on Hebrew documents from the court of Abraham Maimonides. ${ }^{89}$ However, the Geniza also reveals Judeo-Arabic documents signed by Jehiel b. Eliakim, ${ }^{90}$ though not necessarily written in his hand. Since Abraham

\footnotetext{
83. TS 13 J 27.11, 1. 19-20, translated by Goitein (GOITEIN 1967, I, p. 67) and Cuffel (CUFFEL 1999, p. 75).

84. CUFFEL 1999, p. 74; see also Goitein (GoITEIN 1967, I, p. 67).

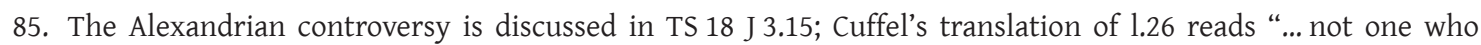
delivers judgment by means of a translator..." (Judeo-Arabic: "ולא אן יחכם בתרגמאן", transcribed by Motzkin in MOTZKIN 1965, II, p. 161 and translated by him as "not one who would make legal decisions through an interpreter". MOTZKIN 1965, I, p. 83.)

86. CUFFEL 1999, p. 74, citing PRAWER 1988, p. 88.

87. For a brief discussion of Jehiel b. Eliakim, see GOITEIN 1967, II, p. 515, section 30.

88. See the letters published in MANN 1970, II, p. 301-306.

89. See, for instance: Mosseri A 72, Mosseri A 111, and TS 12.126.

90. See, for instance: TS $6 \mathrm{~J} 1.1$ and TS $8 \mathrm{~J} 32.7$.
} 
Maimonides himself explicitly forbad witnesses to sign a document the language of which they could not understand, ${ }^{91}$ and since the Geniza reveals Abraham Maimonides to have jointly signed documents along with Jehiel b. Eliakim, ${ }^{92}$ it is unlikely that Jehiel b. Eliakim had no comprehension whatsoever of Judeo-Arabic, even if he may have preferred to write his own letters and documents in Hebrew.

Having found the communicative function of Hebrew to have played an unclear role in Maimonides' choice of language in composing the Mishneh Torah, it would also seem that the communicative function of Hebrew played an unclear role in the choice of language in the documents of the court of his son Abraham Maimonides. The possibility that the scholarly elite represented a smaller proportion of the 13th century immigration than Goitein and others envisioned cannot be rejected, nor can the possibility that much of the scholarly elite strove to integrate linguistically into Egyptian Jewish society by learning JudeoArabic. The role of legal documents as a whole in 13th century Egyptian Jewish society will now be examined in greater detail in order to trace out other possible explanations for the choice of language in the documents of Abraham Maimonides' court.

\section{Beyond Communication: Language Choice and Communal Identity}

The Social and Legal Role of Jewish Legal Documents in the 13th century

Although Cohen's claim that Hebrew played a role in establishing internal communication within the Geonic elite seems not to explain Maimonides' choice of Hebrew in the composition of the Mishneh Torah, it would seem that the production of documents by the Jewish court and for its own use might fit the model of "speakers of European vernaculars from the elite (notably churchmen) [who] used Latin, especially when corresponding about political or ecclesiastical affairs". As explained by Goitein, the dissemination of the Mishneh Torah in Hebrew returned to Hebrew its status as the official language of Jewish legal writing, a status perhaps not seen since the composition of the Mishnah itself in the second century C.E., and Jewish courts throughout the Nile Delta periodically adopted it in producing documents for their own use. The use of Hebrew by the elite, then, could be seen as affirming their status as the elite, as both the subject and the audience of those documents was the elite community of Jewish jurists and notaries.

However, there are at least two problems with this understanding: first, other genres of legal writing, including both legal monographs and the responsa literature, did not experience a resurgence of Hebrew contemporaneous with that ascribed to court documents; and, second, documents of these courts were not necessarily produced by the elite for their own exclusive usage. These are essentially two aspects of the same problem:

91. Cf. ABRAHAM BEN Moses Ben MAIMON, FREIMANN et al. 1937, p. 155-158, \#100.

92. GOITEIN 1967, II, p. 515 section 30. 
first, that the elite did not rely increasingly upon Hebrew in its in-group communication beyond these court documents; and, second, that the aspect of literary production which did experience a resurgence of Hebrew, court documents, was ultimately destined for individuals beyond the Jewish elite.

The social and legal function of the documents of the Jewish court of medieval Egypt in the context of medieval Egyptian society as a whole is an area which has received comparatively little attention, ${ }^{93}$ though Wakin has examined the social and legal role of documents in medieval Islamic law and society. ${ }^{94}$ Wakin explains that medieval Islamic legal formularies dealt with the divergence of opinion among the major legal schools (ihtilāf) through the principle of "precaution" (ihtiyāt). ${ }^{95}$ This concern reflects the reality of rivalry between the major schools of Islamic law and the establishment of parallel courts representing these rival schools within a region or even within a single locale. In light of this reality, parties to an agreement might find themselves making recourse to a court representing a legal school other than that of the court in which they initially made that very agreement; furthermore, even $q \bar{a} d \bar{l} \bar{l}-\mathrm{s}$ within a single legal school might hold radically different legal opinions, demanding different clauses in agreements in order to declare them valid. To withstand this sort of challenge, composers of Islamic formularies and notaries themselves composed what could be called hyper-conservative documentary forms, detailing aspects of agreements and responding to legal concerns which were entirely irrelevant to the major exponents of the legal school which actually produced those agreements.

A similar phenomenon may have obtained in the courts of the Jewish community, not least because the Jewish Rabbanite and Karaite courts in Fusțāt functioned in parallel as did the Islamic Mālikī and Šâfi ī courts. ${ }^{96}$ Indeed, Rustow identifies Karaite and Rabbanite scribes incorporating language that suggests what she calls "legal reciprocity" in marriage documents (among others). In her formulation, this meant that for scribes,

both sets of customs were recognized as equally valid. Those clauses were the work of court clerks who lent their imprimatur to the marriages, combining elements of the Rabbanite and Qarite legal formularies in such a way as to suggest their recognition of the validity of both. ${ }^{97}$

93. A number of studies have examined legal documents themselves, often with the end of describing a specific social institution such as marriage or divorce, most prominently FRIEDMAN 1980, FRIEDMAN 1986, and GIL 1976; though also at times with an eye towards establishing a formulary (see WEISS 1967 and WEISS 1970); or composing the history of a particular family (see MoTZKIN 1965).

94. ȚAHĀWI and WAKIN 1972, particularly p. 1-10. Lawrence Rosen examines the role of documents in contemporary Islamic courts in ROSEN 2000, p. 5, 73. See also EL-LEITHY 2011, where El-Leithy points out how documents could be used as part of a broad social strategy (ibid., p. 404).

95. ȚAHĀWİ and WAKIN 1972, p. 32.

96. For a discussion of the establishment of parallel courts under the Ayyūbids, see LAPIDUs 1972; Lapidus points out in LAPIDUS 1972, p. 282) that the Fāțimids appointed qā as well as the two Sunnī schools just mentioned.

97. Rustow 2008, p. 265. 
Rustow explains that Jewish scribes were familiar with both Rabbanite and Karaite legal traditions, leading to a sort of common legal argot. Indeed, Jewish notarial practice may well have utilized the very same precaution employed by Islamic courts, composing their documents in a manner designed to insure the admissibility of Judeo-Arabic documents in Islamic courts as well as Jewish courts; Rustow notes that the principal function of the court system "was to write documents that would be upheld in other courts of law". 98 Supporting this possibility is Wakin's explanation that written documents themselves do not carry probative force according to Islamic legal theory, ${ }^{99}$ but rather "[j]ust as in the case of private documents, which had no value without the attestation of two or more witnesses to their contents, the text of public documents also required oral testimony". 100 The aforementioned affinity between Judeo-Arabic and spoken Arabic adduced by scholars suggests that oral testimony introduced by reading a Judeo-Arabic document may well have been comprehensible to an Islamic court used to hearing testimony in spoken Arabic. Although Wakin explains that the actual practice of writing documents and their admissibility in courts did indeed take hold over the course of the early centuries of Islam, ${ }^{101}$ Lawrence Rosen describes the persistence of orality in Moroccan courts in the contemporary period. ${ }^{102}$ With this orality in mind, it seems logical that Jewish notaries might have composed documents in Judeo-Arabic which could actually have been read into evidence and confirmed by Muslim witnesses in Islamic courts. Indeed, terms often appear in Judeo-Arabic which clearly come from Islamic law and culture referring in calque to Jewish legal and cultural institutions, even where the Judeo-Arabic term parallels its Hebrew referent only imperfectly. ${ }^{103}$ Noting the usage of "al-qurān" in Judeo-Arabic to refer to "scripture", ${ }^{104}$ Joshua Blau writes that "... sometimes the most hallowed matters of Judaism are denoted by terms borrowed from Islam". ${ }^{105}$ It would seem, then, that the potential audience of the documents of the Jewish court extended beyond the Jewish elite not only to claimants in the Jewish courts themselves, but to the elite within Islamic legal culture. With much of the substantive portion of Judeo-Arabic legal documents utilizing Islamic legal terminology and with Jewish notaries employing precaution in legal formulae which would allow their documents to be read into evidence in Islamic courts, the court records of the Cairo Geniza cannot be seen as occupying the same social space as the

98. RUSTOW 2008 , p. 287. Although Rustow argues that "[t]he principal function of the court system was not to reinforce the central authority of the yeshivot,", (ibid.) I argue here that the court was indeed concerned with maintaining its own relevance as a communal institution.

99. TִAHĀWI and WAKIN 1972, p. 4-5.

100. ȚAHĀĀI and WAKIN 1972, p. 7.

101. ȚAHĀĀI and WAKIN 1972, p. 9-10.

102. ROSEN 2000, p. 5.

103. BLAU 1999, p. 153.

104. BLAU 1999, p. 159.

105. BLAU 1999. 
Hebrew letters of the geonim, which were intended to impress on their Jewish readers the sacrality and elevated role of the academies of Palestine and Babylonia.

If Goitein is correct that the resurgence of Hebrew in the documents of the court of Abraham Maimonides was partly due to the use of Hebrew by Maimonides in composing the Mishneh Torah, then this resurgence did not emerge out of a desire on the part of the religious elite to expand its use of Hebrew in discussing its internal religious or political affairs. Furthermore, as I have explained, the impetus for the resurgence of Hebrew may not primarily have been recourse to the communicative function of the language. Therefore we should consider the possibility that Abraham Maimonides made recourse to the grandiloquent function of Hebrew in at least some of the documents of his court.

\section{The "Grandiloquent Role" and the Documents}

When we examine a few of the Hebrew and Aramaic documents of Abraham Maimonides' court, we find that the role which Drory describes as "festive" or "grandiloquent" was central to the production of these documents, while the "communicative" role was actually somewhat peripheral. First of all, it is worthwhile noting that while significant, this "resurgence" may not have amounted to more than ten percent of the total documentary production of the court of Abraham Maimonides, though it is difficult to make any estimate whatsoever with too great a measure of confidence. ${ }^{106}$ Among the documents from Abraham Maimonides' court that are either published, mentioned in the extant literature, or transcribed in the electronic database of documents at the Princeton Geniza Project, ${ }^{107}$ I found some thirteen such documents in Hebrew and Aramaic, ${ }^{108}$ though a number of these documents are in a state of preservation that does not allow for a full analysis of

106. The estimate of ten percent comes from seeing the thirteen documents identified in footnote 108 below in the context of the 140 or so documents in DELBES 1992 dated to the time of Abraham Maimonides' court. Although some of the dated documents mentioned in DELBES 1992 are not court documents at all, let alone documents from the court of Abraham Maimonides, a countervailing number of documents are likely excluded by DELBES 1992 since his survey was restricted to documents in the Cambridge Geniza collections.

107. This includes primarily (but not exclusively) a brief survey of documents from Abraham Maimonides' court mentioned in GOITEIN 1967; a survey of DELBES 1992 for the years of Abraham Maimonides' rule (1204-1237); MOTZKIN 1965; GOLB 1958; and MANN 1970; as well as a search of the database of electronic transcriptions of more than four thousand documents in the Princeton Geniza Project Browser (accessible through http://gravitas.princeton.edu/tg/tt/) for documents which are attributable to the court of Abraham Maimonides. Hebrew documents were also found in the publication of S. Assaf ASSAF 1946, p. 170-172). My own doctoral dissertation (ACKERMAN-LIEBERMAN 2007) happened to contain two such documents, which were the initial inspiration for this study.

108. For the purposes of this part of the study, documents containing Hebrew which are nonetheless primarily in Aramaic will be included, since both Aramaic and Hebrew penetrated Jewish communities in both Christian Europe and in the domain of Islam. These documents bear shelf-marks Mosseri A 11, Mosseri A 72, Mosseri A 111, TS 12.126, TS 16.335, TS 8 J 6.5 Verso, TS 8 J 6.8, TS 13 J 4.3, TS 18 J 1.31, TS AS 145.17, TS AS 147.3, ULC Or $1080 \mathrm{~J} 11$, and ULC Add 2586. 
their contents. ${ }^{109}$ In at least one of these documents, even a cursory examination suggests that its composition in Hebrew is unsurprising. This is Mosseri A 72, ${ }^{110}$ a prozbul signed by the aforementioned Jehiel b. Eliakim of Aleppo and Elijah b. Zechariah. ${ }^{111}$ Since a prozbul, a document entitling a creditor to claim his debts after the sabbatical year despite a biblical prohibition against doing so, had no equivalent in Islamic law, such a document would have no standing whatsoever in an Islamic court. Thus, the aforementioned technique of "precaution" applied by Muslim (and, perhaps, Jewish) notaries would have been irrelevant: a Jewish debtor claiming in an Islamic court that his debt had been nullified by the sabbatical year would likely have been laughed out of that court. With no possibility of its admissibility into evidence in an Islamic court, with no corresponding exemplars from the Islamic formulary literature, and without even a Judeo-Arabic exemplar from the Jewish formulary literature upon which to rely, ${ }^{112}$ the composition of such a document in Hebrew would be predictable, even expected. Further, it can be asserted that the "communicative" function of detail in such a document was subordinate to its symbolic role for a number of reasons: first, there was no consensus within the medieval Jewish community as to the applicability of the sabbatical laws to debts. ${ }^{113}$ Second, despite its appearance in the formulary literature ${ }^{114}$ and an explicit ruling by important medieval scholars including Maimonides and his French contemporary Jacob b. Meir Tam as to its applicability, ${ }^{115}$ few documentary examples of the prozbul survive, ${ }^{116}$ suggesting that this practice may have been more followed in the breach than as a rule. Therefore, such debts would presumably be collected not only by those who actually composed and executed prozbul documents, but also both by those who breached the sabbatical laws with impunity and those who held such laws not to be applicable. The execution of the prozbul, then, should be seen in part as an individual's declaration of loyalty to Jewish norms and to the Jewish court rather than a practical vehicle to effect debt collection; such a declaration would be essentially disconnected from the detailed content of the document itself. The

109. This includes TS 8 J 6.8 and TS 13 J 4.3. According to notes in the Princeton Geniza Browser, the Hebrew content in TS $8 \mathrm{~J} 6.5$ Verso is a handwriting exercise. This content is in Hebrew, though it is only the introduction and the conclusion of a document-form, often written in Hebrew even when the body itself was written in JudeoArabic.

110. For a transcription of this document, see ASSAF 1946, p. 170-171.

111. For a brief discussion of Elijah b. Zechariah, see GoITEIN 1967, II, p. 515 section 29.

112. It is possible that such an exemplar did exist, but the published sections of Sa'adya Gaon's Judeo-Arabic formulary (BEN-SASSON 1983-1985 and ASSAF 1943) do not contain a formula for a prozbul, nor do the collections of documents aggregated by Gershon Weiss in his attempts to reconstruct the formularies of Hillel b. Eli and Halfon b. Manasseh (WEISS 1967 and WEISS 1970).

113. Assaf points this out in ASSAF 1946, p. 170.

114. See, for example, the 12th century formulary 'Itțur of Isaac b. Abba Mari (ISAAC BEN ABBA MARI and GLANOVSKY 1969).

115. ASSAF 1946, p. 170 nn.17-18.

116. As noted by Assaf (ASSAF 1946, p. 171). 
"communicative" function of the prozbul should then be seen as subordinate to its symbolic function in establishing Jewish identity, a function emphasized by the use of Hebrew.

The communicative function may have also played a subordinate role in another of the documents, TS 18 J 1.31, a Hebrew and Aramaic court record dated to March 1213 C.E., in which an individual acknowledges having received from his grandmother the entire share of assets due him from his father's estate, for which she was apparently executrix, releasing her from all future claims. Release documents certainly played a prominent role in the social and economic life of the Jewish community of medieval Egypt, ${ }^{117}$ though the fact that much of the language in release documents is highly-formulaic itself suggests that the communicate role per se is subordinate. Release documents attest to the fact that claims have been settled between two or more individuals, but they themselves do not necessarily record the settlement. Focusing on the act of release rather than the actions which were the necessary precursors to the act of release, which in the case under discussion would likely mean a full accounting by the grandmother of her son's estate, and delivery to her grandson of the assets from the estate, release documents perform primarily a symbolic and ritual or, to use Drory's term, "festive" function rather than a communicative function. The festive nature of this particular document is amplified by the fact that it is written in a calligraphic hand, though this may have been the case for other reasons as well.

On the other hand, several of the other Hebrew documents involve issues of personal status or family law that would seem to be internal to the Jewish community: Mosseri A 11 reveals a dyer en route to Palestine appointing an executor in Fustạt to distribute his assets in the event of his disappearance; and even more clearly in TS 16.335, "a physician in a small provincial town empowers the judge Elijah in Fusțāt to betroth for him a widow from Marrakesh, Morocco, who lived in the capital". ${ }^{118}$ Likewise, it is possible that Mosseri A 11, a loan document which essentially involves the sale of wine for future payment, would prove difficult to enforce in an Islamic court, both because of the prohibited nature of the object of sale and because of controversy in Islamic law surrounding transactions involving future payment for a commodity which changes hands on the spot. ${ }^{119}$ For these documents, it would seem that Hebrew was used not because for its greater communicative force per se but because the substance of these documents was such that they would probably not find their way into an Islamic court. Indeed, in the case described by Mosseri A 11, the parties would presumably have been decidedly unhappy if the document did find its way into an Islamic court.

The possibility that the content of these documents influenced their language choice resonates with a distinction elucidated by Benjamin Hary in his historical and sociolinguistic

117. See ACKERMAN-LIEBERMAN 2007, I, p. 28-43, 129-130.

118. GOITEIN 1967, III, p. 276-277.

119. In Islamic law, this sort of transaction is called «ribā al-nasī'a»; see VoGEL and HAYES 1998, p. 74ff for a brief discussion of the controversial nature of this type of transaction in Islamic law. For a more detailed discussion of unlawful gain in Islamic law, see ABŪ 'L-WALİD MUḤAMMAD B. AḤMAD IBN RUSHD n.d., I, p. $158 f f$. 
study of multiglossia in Judeo-Arabic. ${ }^{120}$ Hary's analytical introduction explains that "in general terms one may say that multiglossia tends to be more topic-centered while bilingualism is more participant-triggered". ${ }^{121}$ Although the shift to and from Judeo-Arabic and Hebrew is generally considered a bilingual shift, the construct of switching language registers in a multiglossic society and thereby relying on a patois of Aramaic, Hebrew, and Judeo-Arabic in its documents may provide a useful construct within which the resurgence of Hebrew in the documents of the court of Abraham Maimonides can be viewed.

\section{The Role of Linguistic Code-Switching and the Historical Context of the Documents}

Whether to demonstrate one's loyalty to the Jewish court and its norms, to effect changes in personal status according to those norms, or even to avoid the possibility of adjudication of one's case according to Islamic norms, a significant impetus underpinning the behaviors described by all these documents should be seen as the establishment of Jewish identity. Likewise, in her survey of linguistic code-switching and the establishment and maintenance of communal boundaries, Bonnie Urciuoli explains that "what does exist, in any society, is the fact of linguistic variation from which people deploy language forms in 'acts of identity.' From such acts, people's sense of community, group, and language emerge in specific places and times". ${ }^{122}$ Although scholars of linguistics have focused primarily upon code-switching as an oral phenomenon manifest in discrete (often oral) conversations, ${ }^{123}$ it should be pointed out that even those legal documents written primarily in Judeo-Arabic ordinarily contain significant selections of Hebrew or Aramaic formulae, often included at the beginning or the end of their texts. Thus, even without broadening the definition of code-switching to include several documents written within a single sitting of the court or even the total production of the court as a whole as a "communicative episode", the adoption of Hebrew or Aramaic for the body of a legal document in addition to its introduction and conclusion can and should be seen as a code-switching episode shifting away from the expected Judeo-Arabic. In sketching out precisely when one might expect to find code-switching, Urciuoli explains that "[c]ode contrast is much more likely to emerge in switching in the kinds of public places in which politicization of identity is a direct issue". ${ }^{124}$ The nature of the specific issues administered by the court in the Hebrew and Aramaic documents discussed above reflect the centrality of identity issues. As Joan Argenter writes concerning the Jewish community of 14th and 15th century Spain,

$[\mathrm{m}]$ embership in the Jewish community might be externally constructed-i.e., assigned from the outside; however, membership in the community of practice was internally constructed.

120. HARY 1992.

121. HARY 1992, p. 5.

122. URCIUOLI 1995, p. 532.

123. See, for instance, Monica Heller's definition of codeswitching as «the use of more than one language in the course of a single communicate episode. (HELLER 1988, p. 1).

124. URCIUOLI 1995, p. 528. 
For participants, enacting the performance that created that community of practice was also a way of enhancing their membership in the Jewish community. ${ }^{125}$

The choice of Hebrew in these documents should therefore be seen as a vehicle whereby the court was able to enhance participants' membership in the Jewish community, as well as its own role as the desirable venue for adjudication within that community.

Yet when we focus on code-switching as a key to the creation of a shared identity we deemphasize an essential corollary: the "in-group" necessarily creates an "out-group". In her study "Code-Switching and Authority in Late Medieval England", Mary Catherine Davidson explains that "a speaker might deploy this 'we' code to construct his position among literate peers... or enforce his specialized status over monolingual laity... [H]e can also exercise his literate status when positioning himself against an outgroup member who is a social superior". ${ }^{126}$ Thus, while Goitein may well be correct in adducing a connection between the use of Hebrew in the court of Abraham Maimonides and the influx of nonArabic-speaking immigrants which preceded that linguistic shift, a fuller explanation of this linguistic shift begs at least an exploration of the ramifications of this code-switching for identity politics in the broader context of early 13th century Egypt.

The period delimited by Maimonides' arrival in Egypt in 1165 C.E. and his son Abraham Maimonides' death in 1237 C.E. roughly parallels the emergence and flowering of the Ayyūbid dynasty of Egypt, which ruled from 1174 to 1250 C.E. Subtle demographic changes must have been afoot during this period, as (for economic reasons) "the Ayyūbids permitted Europeans - mainly Italians, with some French and Catalans - to settle in Alexandria. These seem to have been present in fairly large numbers, if the three thousand European merchants arrested in the Fifth Crusade are any indication". ${ }^{127}$ The influx of Europeans involved with trade may have been a general trend of which French and German Jewry was a component, perhaps providing an additional explanation of the migration of Jews described by Cuffel. Further, as noted by Alfred Ivry, the shift from the Šíi Fātimid empire to the Sunnī Ayyūbids "was more than a change of clerics and courts of law, it betokened endorsement of a different conceptualization of Islam, politically and theologically". ${ }^{128}$ Yet this sea change did not simply involve a shift in the legal orientation in the direction of Sunnī Islam; according to Michael Chamberlain, the ideological policy of the Ayyūbids "was directed at Sunnīs as much as Shi is... Șalāh al-Dīn's son and successor, also seems to have been more concerned with asserting his authority over Sunnis that with the extirpation of Shi ism..." ${ }^{129}$ Rather, Ayyūbid policy, at least at the start of the dynasty, seems to have been to foster the development of institutions with which it was doctrinally aligned: "One condition of Șalāh al-Dīn's waqf foundation deeds was that those appointed to madrasas be Ash'arite

\footnotetext{
125. ARGENTER 2001, p. 387.

126. DAVIDSON 2003, p. 480.

127. CHAMBERLAIN 1998, p. 230.

128. IVRY 1995, p. 271.

129. CHAMBERLAIN 1998, p. 232.
} 
in doctrine". ${ }^{130}$ Likewise, the subtle acknowledgement of (Sunnī) Šăfiīi predominance in Egypt by the Fātimids, who had also appointed both (Sunnī) Mālikī qādì̄-s of and qādì-s of Šìi orientation ${ }^{131}$ gave way to an Ayyūbid policy which appointed only Šăfi îs to the role of chief $q \bar{a} d \bar{l}$. Although the Mamlūks would come to appoint four chief $q \bar{a} d \hat{\imath}-\mathrm{s}$, one from each of the Sunnī legal schools, in 1265 C.E. under the Mamlūk sultan Baybars, ${ }^{132}$ this sea change came about more than twenty years after Abraham Maimonides' death - although Baybars had laid the groundwork for this decision a few years earlier.

Jewish communal organization seems also to have undergone a shift in this period, as appointments to judicial posts were made or at least ratified by Ayyūbid officials. ${ }^{133}$ In the face of an administration that gave Sunnī institutions an air of officialdom and demanded its imprimatur on appointments to the Jewish court, it would be unsurprising for Jewish communal leadership to seek ways to assert its own legitimacy and control over its own constituents.

This power struggle between the Jewish court and its broader environment is set in relief by Goitein's statement that “[t]he dangerous practice of turning to the Muslim government even in controversies of a purely religious nature became rampant in Ayyūbid times". ${ }^{134}$ Goitein explains that attempts by Abraham Maimonides to introduce pietistic ritual reforms into Jewish worship were rebuffed following an appeal by opponents of these measures to the Ayyūbid sultan al-Malik al-'Ádil (r. 1200-1218 C.E.). In her article "At the Limits of Communal Autonomy: Jewish Bids for Intervention from the Mamluk State", 135 Rustow explains that Ayyūbid officials were actually reluctant to become involved in Jewish intracommunal affairs, and only did so when "the initiative for government intervention came from the Jews themselves". ${ }^{136}$ However, while Goitein concluded that Jewish "communal life was left mainly to their own initiative", ${ }^{137}$ Rustow identifies a transformation in the nature of outside involvement from the Fātimid to the Ayyūbid periods: "One can, in fact, sense the shift from the chancery alone to a combination of the chancery and the judiciary during the Maimonidean incident itself..." 138 In the incident described by Rustow, the Ayyūbids' expansion and centralization of the Sunni judiciary provided Abraham's detractors with more arrows in their quiver with which to attack the Nagid - even if these changes did not mean greater involvement in Jewish affairs by the Ayyūbid chancery and judiciary per se. Yet amidst an environment in which disgruntled members of the Jewish community felt increasingly comfortable making recourse to Muslim judges, code-switching to Hebrew in the documents of the court of Abraham

\footnotetext{
130. CHAMBERLAIN 1998. For a discussion of Ash'arite doctrine, see GoLDZIHER and LEWIS 1981, p. 67-115.

131. LAPIDUS 1972, p. 282.

132. Cf. RAPOPORT 2003 for a discussion of this turning point in the history of the Egyptian judiciary.

133. Cf. GOITEIN 1967, II, p. 405-406.

134. GOITEIN 1967, II, p. 406.

135. RUSTOW 2009.

136. RUSTOW 2009, p. 145.

137. GOITEIN 1967, II, p. 407.

138. RUSTOW 2009, p. 145-146.
} 
Maimonides would have generated a countervailing force, subtly opposing the authority of the Sunnī courts in the Ayyūbid sphere as intra-communal documents and affairs in general would have been less intelligible to Muslim judges.

\section{Conclusion}

Although Jewish courts may have maintained a significant measure of influence over the day-to-day life of his community even in the time of Abraham Maimonides, his own lack of success in instituting his pietistic religious reforms is symptomatic of a decline in that influence at the beginning of the 13th century. Political and demographic changes were afoot in this period which certainly contributed to this decline. Rather than seeing the resurgence of Hebrew as an effort to communicate with immigrants coming from France and Germany to Egypt and Palestine, and particularly to Alexandria, I suggest here that the periodic use of Hebrew by the Jewish court should be seen as evidence of situational codeswitching which asserted the role of the court as the desirable venue for adjudication for the Jewish community and as a response to challenges to the authority of the Nagid from the Ayyūbid administration. In the words of Susan Gal,

[s]peakers create meaning in conversation by juxtaposing linguistic elements that they consider to be from separate language systems, each system linked with one category of people or one domain of activities. Attitudes toward the languages are, implicitly, evaluations of the groups, activities, and social relations of solidarity or power that they index. It is this overarching symbolic opposition that makes the choice of one language or another an interpretable act that invites conversational inferences, much like Gricean implicatures, usually about the speakers' relationship, identities, or conversational intentions. ${ }^{139}$

The choice of Hebrew in some of these documents undoubtedly emerges from the symbolic function which those specific documents might have served, the notable examples being the prozbul (Mosseri A 72) and documents involving family law or personal status issues internal to the Jewish community. But the adoption of Hebrew in documents such as partnership agreements written on behalf of associates who almost certainly knew JudeoArabic $^{140}$ should be seen as an effort on the part of the court to use its choice of language as a vehicle to reinforce subtly both its independence and its power in the face of challenges both from the Jewish community itself and from its host culture in medieval Egypt.

Of course, Hebrew did not completely supplant Judeo-Arabic as the language of the Jewish court in the early 13th century. Indeed, the aforementioned pair of documents concerning the sale of a slave-girl came from Abraham Maimonides' very court. Yet it would seem that the Jewish court's role as the voice of madhab al-yahūd, as an 11th century

\footnotetext{
139. GAL 1987, p. 639.
}

140. For example, TS 12.126 and TS AS 147.3. In the case of TS 12.126, the by-names of the parties to the agreement are in Judeo-Arabic, strengthening this conjecture. 
letter styles Jewish practice, amidst other madāhib, gave way to the Jewish court's role as representative of millat al-yahūd, the distinctive and perhaps legally separate community of the Jews, to which Moses Maimonides refers in a letter from around 1200 C.E.

\section{Bibliography}

\section{Sources}

Abraham ben Moses ben Maimon, Abraham Hayyim Freimann et al., Teshuvot, Jerusalem, Mekitṣe Nirdamim, 1937.

Ibn Rushd, Bidāyat al-mujtahid wa-nihāyat al-muqtașid, Cairo, al-Maktaba al-Tawfiqiya, no date.

Assaf, Simha, Sefer ha-shețarot shel Rav Sa' adyah, Jerusalem, Mosad ha-Rav Kook, 1943.

Ben-Sasson, Menahem, "Fragments from 'The Book of Testimony and Documents' of Rabbi Saadiah Gaon", Shenaton ha-mishpat ha-'Ivri: shel ha-Makhon le-heger ha-mishpat ha-'Ivri, ha-Universita ha-'Ivrit bi-Yerushalayim 11-12, p. 135-278, 1983-1985.

Bodleian Library (BODL), Oxford University.

Hai ben Sherira and Simha Assaf, Sefer ha-shețarot, Jerusalem, Azriel Press, 1930.

Ibn Ḥazm and Aḥmad Muḥammad Shākir, al-Muhallā, Cairo, Idārat al-Ṭibāạah al-Munīrīya, 1928.

Isaac ben Abba Mari and Meir Jonah Glanovsky, Sefer ha-Itțur, Jerusalem, 1969.

Maimonides, Moses, Mishneh Torah, New York, 1975.

Maimonides, Moses, and Joshua Blau, Teshuvot ha-Rambam Jerusalem, Mekitse nirdamim, 1986.

Mosseri Geniza Collection (Mosseri), Jerusalem (currently on loan to the Cambridge Genizah Unit, Cambridge University Library).

Müller, Joel, Teshuvot ge’one Mizrah u-Ma'arav, Jerusalem, 1966.

Sa'adya ben Joseph, Israel Davidson et al., Kitāb jāmi al-șalawāt wa-l-tasābīh, Jerusalem, Hevrat Meqitṣe Nirdamim, 1970.

Sherira ben Hanina, Hai ben Sherira et al.Teshuvot ha-ge'onim: she'elot u-teshuvot mi-kama ge'onim uve-yihud me-Rav Sherira gảon, mi-beno Rav Hai gảon umeha-Rav Yishaq Alfasi, A. Harkavy, M. Kasher and J. F. Perla. Jerusalem, Șevi Hirsh, 1965.

Taylor-Schechter Geniza Collections (TS), Cambridge University Library.

University Library Cambridge (ULC), Geniza Collections.

\section{Studies}

ACKERMAN-LIEBERMAN, Phillip I. 2007, A Partnership Culture: Jewish Economic and Social Life Seen through the Legal Documents of the Cairo Geniza, Ph.D. Dissertation, Princeton University.

ACKerman-Lieberman, Phillip I. 2010, "Legal Writing in Medieval Jewish Cairo", in S. Bhayro and B. Outhwaite, 'From a Sacred Source': Geniza Studies in Honour of Professor Stefan C. Reif, Leiden, Brill, p. 1-24.

ARGENTER, Joan A. 2001, "Code-switching and dialogism: Verbal practices among Catalan Jews in the Middle Ages", Language in Society 30/3, p. 377-402. 
AsHTOR, Eliyahu 1959, "Prolegomena to the Medieval History of Oriental Jewry", Jewish Quarterly Review n.s. 50/2, p. 55-68, p. 147-166.

[Online]http://www.jstor.org/stable/1453196 DOI: 10.2307/1453196

ASSAF, Simha 1946, Mekorot u mehkarim be toledot yisrael, Jerusalem, Mosad ha Rav Kook.

BLAU, Joshua 1999, The Emergence and Linguistic Background of Judaeo-Arabic: A Study of the Origins of NeoArabic and Middle Arabic, Jerusalem, Ben-Zvi Institute for the Study of Jewish Communities in the East.

BRODY, Robert 1998, The Geonim of Babylonia and the Shaping of Medieval Jewish Culture, New Haven, Yale University Press.

Chamberlain, Michael Milton 1998, "The Crusader Era and the Ayyūbid Dynasty”, in C. F. Petry, The Cambridge History of Egypt, Volume 1, Cambridge Cambridge University Press, p. 211-241.

COHEN, Mark R. 2007, "On the Interplay of Arabic and Hebrew in the Cairo Geniza Letters", in J. P. Decter and M. Rand, Studies in Arabic and Hebrew Letters in Honor of Raymond P. Scheindlin, Piscataway, New Jersey, Gorgias Press, p. 17-36.

COHEN, Mark R. 2007, "On the Interplay of Arabic and Hebrew in the Cairo Geniza Letters", in J. P. Decter and M. Rand, Studies in Arabic and Hebrew Letters in Honor of Raymond P. Scheindlin, Piscataway, New Jersey, Gorgias Press, p. 17-36.

CUFFEL, Alexandra 1999, "Call and Response: European Jewish Emigration to Egypt and Palestine in the Middle Ages”, Jewish Quarterly Review 90/1 2,p. 61-102.[Online] http://www.jstor.org/stable/1455396 DOI: $10.2307 / 1455396$

DAVIDSON, Mary Catherine 2003, "Code-Switching and Authority in Late-Medieval England", Neophilologus 87/3, p. 473-486. DOI: 10.1023/A:1023943026035

DELBES, Pierre 1992, «Les documents datés de la Geniza du Caire », Ph.D., Paris, Sorbonne University.

DRORY, Rina 2000, Models and Contacts: Arabic Literature and its Impact on Medieval Jewish Culture, Leiden, Brill.

EL-LeITHY, Tamer 2011, "Living Documents, Dying Archives: Towards a Historical Anthropology of Medieval Arabic Archives", Al-Qanțara 32/2, p. 389-434. DOI: 10.3989/alqantara.2011.v32.i2.262

FRIEDMAN, Mordechai Akiva 1980, Jewish Marriage in Palestine: a Cairo Genizah Study, New York, Jewish Theological Seminary of America.

FRIEDMAN, Mordechai Akiva 1986, Ribui nashim be Yisrảel: meqorot hadashim mi Genizat Qahir Jerusalem, Mossad Bialik.

GAL, Susan 1987, "Codeswitching and Consciousness in the European Periphery", AmericanEthnologist 14/4, p. 637-653. DOI: 10.1525/ae.1987.14.4.02a00030

GIL, Moshe 1976, Documents of the Jewish Pious Foundations from the Cairo Geniza, Leiden, Brill.

GoITEIN, S.D. 1959, "Review: Maimonides as Chief Justice: The Newly Edited Arabic Originals of Maimonides' Reponsa", Jewish Quarterly Review New Series 49/3, p. 191-204. [Online] http://www.jstor.org/stable/1453076

GoITEIN, S. D. 1967, A Mediterranean Society: The Jewish Communities of the Arab World as Portrayed in the Documents of the Cairo Geniza, Berkeley, University of California Press.

GoITEIN, S. D. and Joseph Hacker 1980, ha Yishuv be Ereș Yisrảel be reshit ha Islam uvi tequfat ha Șalvanim le or kitve ha Geniza Jerusalem, Yad Yișhaq Ben Șevi.

GolB, Norman 1958, "Legal Documents from the Cairo Genizah", Jewish Social Studies 20/1, p. 17-46. [Online]http://www.jstor.org/stable/4465573 
GOLDZIHER, Ignác and Bernard Lewis 1981, Introduction to Islamic theology and law, Princeton, N.J., Princeton University Press.

HARY, Benjamin H. 1992, Multiglossia in Judeo-Arabic: with an edition, translation and grammatical study of the Cairene Purim scroll, Leiden-New York, E.J. Brill.

HeLleR, Monica, Ed. 1988, Codeswitching: Anthropological and Sociolinguistic Perspectives, Berlin, Mouton de Gruyter.

Hopkins, Simon 2005, "The Languages of Maimonides", in G. Tamer, The Trias of Maimonides, Berlin, Walter de Gruyter, p. 85-106.

IVRY, Alfred 1995, "Ismā̄ ìlī Theology and Maimonides' Philosophy”, in D. Frank, The Jews of medieval Islam: community, society, and identity, Leiden and New York, Brill, p. 271-300.

KENNEDY, Hugh 1981, The early Abbasid Caliphate: a Political History, London, Croom Helm.

LAPIDUS, Ira M. 1972, "Ayyubid Religious Policy and the Development of Schools of Law in Cairo", in A. Raymond, Colloque international sur l'histoire du Caire, Cairo, Egyptian Book Organisation, p. 279-286.

MANN, Jacob 1919, “The Responsa of the Babylonian Geonim as a Source of Jewish History. II: The Political Status of the Jews", Jewish Quarterly Review n.s. 10/1, p. 121-151.

MANN, Jacob 1970, The Jews in Egypt and in Palestine under the Fātimid Caliphs, New York, Ktav.

MotzKIN, Aryeh Leo 1965, The Arabic Correspondence of Judge Elijah and His Family (Papers from the Cairo Geniza): A Chapter in the Social History of Thirteenth Century Egypt, Ph.D., University of Pennsylvania.

PRAWER, Joshua 1988, The History of the Jews in the Latin Kingdom of Jerusalem, Oxford, Oxford University Press.

RAPOPORT, Yossef 2003, "Legal Diversity in the Age of Taqlīd: The Four Chief Qādīs under the Mamluks", Islamic Law and Society 10/2, p. 210-228. [Online] http://www.jstor.org/stable/3399252

REINER, Elhanan 1988, 'Aliya va-'aliya le-regel le-ereș yisrael: 1099-1517, Ph.D., Jerusalem, Hebrew University.

ROSEN, Lawrence 2000, The Justice of Islam: Comparative Perspectives on Islamic Law and Society, Oxford, Oxford University Press.

RUSS-FISHBANE, Elisha 2012, "The Maimonidean Legacy in the East: A Study of Father and Son", Jewish Quarterly Review 102/2, p. 190-223. DOI: 10.2307/1453196

Rustow, Marina 2008, Heresy and the Politics of Community: The Jews of the Fatimid Caliphate, Ithaca, Cornell University Press.

RusTow, Marina 2009, "At the Limits of Communal Autonomy: Jewish Bids for Intervention from the Mamluk State", Mamluk Studies Review 13 /2, p. 133-159.

Simonsonn, Uriel 2011, A Common Justice: The Legal Alliances of Christians and Jews Under Early Islam, Philadelphia, University of Pennsylvania Press.

TA-SHMA, Israel Moses 2001, “The Acceptance of Maimonides' 'Mishneh Torah' in Italy”, Italia 13 15, p. 79-90.

ṬAHĀĀT, Ahmad b. Muhammad and Jeanette A. Wakin 1972, Jāmi al-kabīr fi al-shurūt. The Function of Documents in Islamic Law: the Chapters on Sales from Țahāwī's Kitāb al-shurūṭ al-kabīr. Edited with an introduction and notes by Jeanette A. Wakin Albany, N.Y., State University of New York Press.

TWERSKY, Isadore 1980, Introduction to the Code of Maimonides (Mishneh Torah), New Haven, Yale University Press.

Urciuoli, Bonnie 1995, "Language and Borders", Annual Review of Anthropology 24, p. 525-546. DOI: 10.1146/annurev.an.24.100195.002521 
VoGeL, Frank E. and Samuel L. Hayes, 1998, Islamic Law and Finance: Religion, Risk, and Return, The Hague, Kluwer Law International.

WeISS, Gershon 1967, Documents Written by Hillel ben Eli, A Study in the Diplomatics of the Cairo Geniza Documents, MA Thesis, Philadelphia, University of Pennsylvania. 